\title{
UNDERSTANDING TYPOLOGY AND RELIGIOUS ATTITUDE OF BIMANESE STUDENTS IN UIN ALAUDDIN MAKASSAR
}

\author{
Abdullah \\ UIN Alauddin Makassar \\ Jln. H.M. Yasin Limpo No. 36 Samata Gowa \\ Email: abdullahdul687@gmail.com
}

\begin{abstract}
This article discusses the typology of understanding and the level of diversity of students from Bima district in UIN Alauddin Makassar. The research suggest that the reality of their understanding and religious attitudes consist of several categories: First, the tendency to understand the average Makassar UIN Alauddin student from Bima district to the doctrine of salvation for other religions is quite moderate or inclusive. Then from the four sub-variables of this study indicate that in the two sub-variables the respondents' answers showed a positive tendency, regarding Islamic variables and intellectual discourse and sub perceptual variables about acts of violence in the name of religion. Second, these two sub-variables show a moderate religious understanding and attitude from the respondents which is shown by an appreciative attitude towards the use of intellectual discourse in Islamic studies. The three perception variables about acts of violence in the name of religion, students from Bima UIN Alauddin Makassar have a moderate tendency, and evident from the answers of most respondents to the phenomenon of acts of violence in the name of religion. Fourth, the totality in this sub-variable shows the moderate attitude of respondents who reject all forms of coercion and violence in fighting for religion.
\end{abstract}

Keywords: Typology of Understanding, Religion and Student Attitudes UIN Alauddin from Bima District 


\section{Introduction}

Based on the results of the Ministry of Religion's R \& $\mathrm{D}$ and Education and Training Agency survey conducted in 13 provinces, data found that around $92 \%$ of respondents claimed to always pray, $63.5 \%$ always prayed in congregation, $97.3 \%$ claimed to always perform fasting, and $77 \%$ always pay zakat. ${ }^{1}$

The Ministry of Religion still suggests potential problems in terms of its relation to the understanding and practice of religion. First, the gap is still quite wide between individual piety and social piety in the midst of society. The still high level of deviant social behavior is characterized by, among other things, the high level of corruption, criminal acts, and other social anomaly practices that hinder religious development. Second, even though it is sporadic in nature cases of violent conflict with religious nuances reflecting the rise of radical / fundamental halaqah or religious groups, insights are narrow, shallow, and exclusive and are intolerant of differences among the people. This phenomenon is paradoxical to the mainstream of religious understanding and attitudes, especially moderate Islam. ${ }^{23}$

${ }^{1}$ Badan Litbang dan Diklat Kementerian Agama RI, Survey Tingkeat Kesalehan Masyarakat Muslim Indonesia, Jakarta: Badan Litbang dan Diklat Departemen Agama, 2007),

${ }^{2}$ Bidang Kehidupan Keagamaan Balai Litbang Agama Makassar, Paham dan Sikap Keagamaan Mahasiswa Muslim di Kawasan Timur Indonesia, (Makassar: Laporan Penelitain, $3)$, h. 2 . 
The younger generation, especially students, is a very vulnerable group to be penetrated with enthusiasm and understanding of religious radicalism. A very young age with a burning spirit, and a longing to carry out its religion more comprehensively (comprehensive) makes the young group students - become the most vulnerable social group to penetrate the latent danger of religious fundamentalism with a rigid understanding and radical attitude.

Students from Bima at UIN Alauddin were part of the young generation. Therefore, this study found its significance to find out the understanding tendencies and religious attitudes of students from Bima district in UIN Alauddin Makassar. UIN Alauddin's campus is an Islamic university which of course becomes a meeting place for various religious ideals, ranging from those who tend to be radical, moderate, and even liberal. Therefore, knowing the dominant tendency of students' religious understandings from the Bima area in Alauddin UIN becomes the urgency of this research.

Bima Regency is one of the Autonomous Regions in the Province of West Nusa Tenggara, consisting of 18 Districts, namely; Ambalawi, Belo, Bolo, Donggo, Lambitu, Lambu, Langgudu, Madapangga, Monta, Palibelo, Parado, Sanggar, Sape, Soromandi, Tambora, Wawo, Wera, and Woha ${ }^{4}$ located on the eastern end of Sumbawa Island next to the City of Bima (a fragment of the City of Bima).

4 Permendagri no.137 tabun 2017". 27 Desember 2017. Diakses tanggal 12 Juni 2018 
Geographically, Bima Regency is in the position of $117^{\circ} 40$ "-119 ${ }^{\circ}$ 10" East Longitude and $70^{\circ} 30$ "South Latitude ${ }^{5}$.

Topographically, the area of Bima Regency is mostly $(70 \%)$ is mountainous highland while the rest $(30 \%)$ is flatland. About $14 \%$ of the lowland proportion is rice fields and more than half is dry land. In

The area after the establishment of the Bima City Area based on Law No. 13 of 2002 is 437,465 Ha or 4,394.38 $\mathrm{Km}^{2}$ (before the expansion of $459,690 \mathrm{Ha}$ or $4,596.90 \mathrm{Km}^{2}$ ) with a population of 419,302 people with an average density of 96 people / $\mathrm{Km}^{2}$.

The Bima Regency region has a tropical climate with an average of relatively short rainfall. The average annual rainfall condition is $58.75 \mathrm{~mm}$.

\section{The Relationship among the Bugis, Bima and Macassar}

The kinship and family relationships that were established during the period of 1625-1819 (194 years) were interrupted to this day. The familial relationship between the two great sultanates in the eastern region of Indonesia, namely the Sultanate of Gowa and the Sultanate of Bima, is intertwined to the seventh derivative. This relationship was a cross between the Crown Prince of the Sultanate of Bima and the Crown Princess of the Gowa Sultanate which was intertwined until the sixth derivative, while the VII was the

\footnotetext{
${ }^{5}$ Potensi Daerah Kabupaten Bima. Situs Pemkab Bima
} 
marriage of the Crown Princess of the Sultanate of Bima and the Crown Prince of the Gowa Sultanate.

There are some records found, that the marriage of one of the descendants of Sultan Ibrahim (Sultan Bima to XI) still occurs with the descendants of the Sultan of Gowa, because in 1900 (at the leadership of Sultan Ibrahim), an event was proposed by the Sultanate of Bima to the Gowa Sultanate. Mahar on the proposal is Tanah Manggarai which was controlled by the Bima sultanate since the 17 th century.

\section{A glimpse of the history of travel and the culture of migrating students from Bima at UIN Alauddin}

Most of these residents have a generation or descendants who are educated in Makassar formally and students who choose to study at UIN Alauddin Makassar have the largest number of percentages compared to some universities in Makassar. As proof that those who chose to continue their studies on this green campus until the 2018 school year were 665 people with various faculties within the Alauddin UIN Makassar environment. They have different levels of religious understanding because they are motivated by different departments and different religious doctrines because they have different Islamic organizations and even different Islamic studies. The difference in understanding of Islam among them has relevance to the majors they choose, including student organizations that are extra places where they are cadre or doctrine. 


\section{Theoretical Framework}

\section{Religious Theory}

According to Glock and Stark there are five dimensions of diversity, ${ }^{6}$ namely: First, Dimensions of belief (ideological). This dimension is full of awards where people also commit to a particular theological view and recognize these truths as axioms. Every religion maintains a set of beliefs in which followers are expected to obey.

Second. Dimensions of worship or religious practice (ritaulistik). This aspect includes cult or cult attitudes, obedience, and things people do to express their religious commitment to the realm of symbolic praxis. These religious practices consist of two important categories, namely rituals that refer to a set of rites, formal religious acts and sacred practices which all expect followers to carry out consistently.

Third. Dimension of appreciation (experiential). This dimension contains the fact that all religions are loaded with certain expectations. Even though it is not appropriate to say that someone who has a good religion at a time will achieve subjective and direct knowledge of Ultimate reality. Fourth. Dimension of religious knowledge (intellectual). This dimension refers to the expectation that believers have at least a minimum set of knowledge regarding the basics of beliefs, rites, traditions, and scriptures. And the dimensions of knowledge and belief are clearly related to each other. Because knowledge of beliefs is a requirement for recipients.

${ }^{6}$ Ancok Jamaluddin dkk, Psikologi Islam: Solusi atas Problem-problem Psikologi, (Yogyakarta: Pustaka Pelajar, 1994), h. 77-78. 
Fifth. The dimensions of religious practice (consequential). The consequences of religious commitment refer to the identification of the implications of a person's beliefs, creeds, practices, knowledge, and beliefs about the religion he adheres to. And religious consequences are part and implications of religious commitment.

\section{Religious Understanding Theory}

Religious understanding as a tendency in understanding and religious orientation which is then embodied in the form of attitudes and behavioral diversity, is at least divided into three categories; radical religious understanding, moderate religious understanding, and liberal religious ideology.

Radical religious understanding is the most extreme and exclusive pattern of religious understanding in religious understanding and attitude. According to Hamzah Zada, there are four characteristics of radical Islamic groups, namely; 1) Fight for the implementation of Islam in a kaffah (total), 2) Basing religious understanding and practice on the generation of salaf al-saleh, 3) Hostile to the West with all its products, 4) hostile to liberalism that has entered the Islamic world. ${ }^{7}$

Moderate religious understanding is a viewpoint and religious attitude that is not trapped in two extreme poles, namely radical and liberal. Moderate means being at the

${ }^{7}$ Hamzah Zada, Islam radikal: Pergulatan Ormas-ormas Islam Garis Keras di Indonesia, (Jakarta: Teraju 2002). 
midpoint, not too closed nor free to open. Moderate religious understanding is characterized by a consistent attitude and commitment to religion, but at the same time still open to understanding or discourse that originates from outside his religion. Moderate religious understanding (in this case moderate Islam) also does not desire the application of the totality of political Islam, it is also still open to contextual understanding of Islamic discourse. In contrast to liberalism, moderate understanding still tends to provide boundaries in the space of interpretation and contextualization of religious understanding and practice. ${ }^{8}$

Liberal religious understanding is a religious notion that is at the extreme pole which is the antithesis of radical religious understanding. Liberal religious understanding is characterized by an attitude that is very open to the realm of religious understanding and discourse. Open free space in interpreting and contextualizing religious texts in accordance with the demands of the times. Liberal religious understanding is also usually accompanied by an understanding of religious pluralism which tends to see that the path of salvation is also found in religions outside of Islam. According to Charles Khuzman, the liberal tradition in Islam argues that if Islam is properly understood it is in line with Western liberalism. ${ }^{9}$

h. 34 .

${ }^{8}$ Saleh Haddad, Islam Warna-warni, (Solo: Pustaka Mafaza, 2002),

${ }^{9}$ Charles Khuzman, Wacana Islam Liberal: Pemikiran Islam Kontemporer tentang Isu-isu Global, (Jakarta: Paramadina, 2001), h. xvii. 


\section{Research Methodology}

\section{A. Type of Research}

This type of research is quantitative field research. This quantitative research aims to measure the tendency of religious understandings of students from Bima district in UIN Alauddin through questions in the form of questionnaires that describe the religious ideals they embrace.

\section{B. Data Population}

The population in this study were all Alauddin UIN students enrolled in 8 faculties in UIN with a total number of recruiting data for the 2018 Academic Bureau as many as 23,320 students. From a number of students there were groups of students from Bima district with a total of 665 people.

The number of students from Bima regency is recorded by each faculty within the UIN Alauddin Makassar environment. The distribution of the population of Alauddin's UIN students based on data from the Bureau of Academic and Student Affairs (BAK) of the Alauddin UIN Rector's Office is:

No. Faculty Number Percent

1 Adab and Humanities 82 people 10.24\%

2 Da'wah and Communication 97 people 10.14\%

3 Sharia and Law 102 people $10.69 \%$

4 Tarbiyah and Teacher Training 120 people $22.82 \%$

5 Ushuluddin, Philosophy, and Politics 65 people $7.55 \%$ 
6 Science and Technology 67 people $16.67 \%$

7 Health 53 people $9.39 \%$

8 Islamic Economics and Business 79 people $12.50 \%$

Total of 665 people $100 \%$

Determination of the number of samples using the method of sampling using sample probability with a random technique. ${ }^{10}$ Efforts were made to determine the amount of the sample in this study using Slovin theory $(\mathrm{n}=\mathrm{N} / 1+$ $\mathrm{N} . \mathrm{d} 2){ }^{11} \mathrm{n}=$ number of samples $\mathrm{N}=$ population $\mathrm{d}=$ estimated error rate (error estimation), in this study using a 0.05 error estimate $(5 \%)$

Furthermore, in determining the distribution of sample size for each faculty using a proportional stratified random sampling technique which is sampling if the population has a multilevel or multilevel arrangement. ${ }^{13}$

\section{Variables and Research Questions}

The variable to be measured in this study is the religious understanding of students from Bima district in UIN Alauddin. This variable is then derivated into 4 categories of research questions, namely; Islam and religious pluralism, the formalization of Islam (religious and state

${ }^{10}$ Lihat Suharsini Arkunto, Prosedur Penelitian: Studi Pendekatan Praktek, (Jakarta: Rineka Cipta, 2010), h. 177 dan lihat pula Sugiyono, Metode Penelitian Kuantitatif, Kualitatif, dan

R\&D, (Bandung: Alfabeta, 2011), h. 82

${ }^{11}$ Mohammad Nazir, Metode Penelitian, Jakarta: Ghalia Indonesia, 2005), h. 311. ${ }^{13}$ Sugiyono, loc. cit. 
relations), Islam and intellectual discourse, as well as perceptions of jihad and violence in the name of religion. These four categories are then broken down into 20 questionnaire questions to measure the religious understanding of UIN Alauddin Makassar students.

\section{Data Collection}

Data collection techniques are carried out by using questionnaires as instruments that contain research questions as mentioned above. The data was then captured through the distribution of questionnaires which were then filled in by a number of respondents, namely the Alauddin UIN students as long as they were done on campus or in their respective boarding houses.

\section{E. Data Analysis}

The method used in analyzing data is based on a positivistic paradigm approach, ${ }^{12}$ that is by organizing data into a pattern, category, and description of the basic unit. ${ }^{13}$ The quantitative data processing techniques used in this study are inferential statistical techniques. ${ }^{14}$ Data obtained through questionnaire sheets filled in by respondents were then processed with a Likert scale. The Likert scale is used to measure variables to be translated into variable indicators.

12 Paradigma positivistik pada dasarnya muncul dari proses sintesa terhadap paradigma newtonian yang telah dominan dalam perjalanan sains dan teknologi yang mendominasi lebih kurang tiga ratus lima puluh tahun bahkan sampai era sekarang masih berpengaruh terhadap paradigma pemikiran masyarakat modern.

13 Lexy Moleong, Metodologi Penelitian Kuantitatif, (Bandung: Remaja Rosdakarya, 2007), h. 280.

${ }^{14}$ Sugiyono, op. cit., h. 148. 
Inferential statistics are used for the purpose of generalizing samples over the population, ${ }^{15}$ through a Likert scale with predetermined indicators.

In the data processing process in this study, researchers conducted questionnaire data processing with the help of SPSS 20 data processing which was then analyzed manually by researchers to obtain the desired research data. After processing statistical data, researchers then used data analysis techniques proposed by Miles and Huberman, which included data reduction (data reduction), presentation of data (data display) and conclusions (conclusion drawwing). ${ }^{17}$

The Likert scale used by researchers to arrive at conclusions about the tendency of religious understandings of students from Bima district in UIN Alauddin is scale 4. Thus, each question option is weighted from 1 to 4 . For questions number 1 to number 9 the answers strongly agree to be given weights 4 , agree to be given weight 3, disagree weight 2 , and disagree weight 1 . Then for questions number 10 to 16 weighting values are reversed, disagree weight 4 , disagree weight 3 , agree weight 2 , and strongly agree weight 1 As for categorization Likert scale weight to measure the level of tendency of religious understanding of students from Bima district in UIN Alauddin Makassar, are;

$$
\begin{aligned}
& 1.00-1.50 \text { Very Radical } \\
& 1.51-2.00 \text { Radicals }
\end{aligned}
$$

15 Burhan Bungin, Metodologi Penelitian Kuantitatif: Komunikasi, Ekonomi, dan Kebijakan Publik, serta Ilmu-ilmu Sosial Lainnya, Jakarta: Kencana, 2010), h. 182. ${ }^{17}$ Sugiyono, op. cit., h. 246. 
$2.01-2.50$ Moderate

2.51 - 3.00 Very Moderate

3.00 - 3.50 Liberal

3.51 - 4.00 Very Liberal

\section{FINDINGS AND DISCUSSION}

This study consists of four sub-variables, namely; Islam and issues of religious pluralism, Islam and intellectual discourse, Islamic formalism relating to the relationship between Islam and the State, and perceptions of violence in the name of religion. Islamic sub-variables and religious pluralism ask about religion as a way of salvation, respect for the concept of truth held by other religions, congratulate holidays on adherents of other religions, surrounding religious isukoversion, and issue interfaith marriage. The second subvariable asks responses from respondents about Islam and intellectual discourse, which consists of; the use of a philosophical approach in understanding religious doctrine, the use of social and humanities approaches in the interpretation of the Koran, non-Muslims who study the Koran, and a contextual approach to the interpretation of the Koran. The third sub-variable asks the response from respondents about the formalization of Islam in the State which includes asking about the enforcement of Islamic law, sharia regulations, khilafah Islamiyah, to the extent of Islam as a private and public religion. The fourth sub-variable asks about perceptions of violence in the name of religion which among others asks about the spread of religion by violence, 


\section{Abdullah}

jihad with violence, to the act of jihad by carrying out suicide bombings.

The total questionnaire questions were 20 questions, and the respondents were asked to respond with four choices, namely strongly agree, agree, disagree, and strongly disagree. Based on the respondents' answers, they will be analyzed in a frequency manner and general explanations will be conducted by reading the general tendency of the respondents to all the questionnaire questions contained in the four sub-variables in this study.

\section{A. Islam and Religious Pluralism}

The first sub-variables in this study are about perceptions about Islam and the issue of religious pluralism. There are five questions related to Islam and the issue of pluralism, namely; How do you rate the opinion that all religions are the same as the path of salvation ?, Do religions outside Islam also contain truths that must be respected and respected? In your opinion, is saying congratulations to followers of other religions (eg congratulating Christmas) is permissible? Do you think conversion or conversion is common or common?, and how do you evaluate the practice of interfaith marriage chosen by several believer?

The first question about How do you rate the opinion that all religions are the same as the way of salvation? This question aims to find out the respondent's attitude regarding the position of religion as a way of salvation and the view that there is also a way of salvation outside Islam. Most of the 100 
respondents gave a negative response, namely 30\% of respondents said that they were not in agreement and $40 \%$ of respondents said they strongly disagreed, only a total of 30 respondents gave a positive appreciation, $9 \%$ of respondents said they strongly agreed and $21 \%$ stated agree.

\section{Tabel 1}

How do you rate the opinion that all religions are the same as the way of salvation?

Answer Percent (\%)

Strongly Agree 9

Agree 21

Disagree 30

Strongly Disagree 40

Total of 100

Based on the respondents' answers, it shows that the general tendency of respondents still considers that only Islam is the only way of salvation for humans, in other words, most respondents think there is no way of salvation outside Islam. It can be concluded from this question that the pluralist tendency of respondents is as much as $30 \%$ because it accepts the position of all religions as a way of salvation for its adherents.

The second question more specifically asks the attitude of appreciation to the truth contained in other religions through questions; Do religions outside Islam also contain truths that must be respected and valued? In contrast 


\section{Abdullah}

to the previous question, in this question the general tendency of respondents to give positive appreciation. $70 \%$ of respondents gave a positive appreciation of $50 \%$ agreeing and $20 \%$ stated strongly agree with the statement that religion outside Islam contains truths that deserve respect. On the other hand, $30 \%$ gave a negative response, namely: $20 \%$ of respondents said they did not agree and 10\% stated strongly disagree.

\section{Tabel 2:}

Do religions outside Islam also contain truths that must be respected and valued?

Answer Percent (\%)

Strongly Agree 20

Agree 50

Disagree 20

Strongly Disagree 10

Total of 100

This second question basically states the tendency of tolerance in terms of respect for respect for the truth that is believed by religious believers ...

The third question looks at the tendency of a more praxis view of resonden in relation to the religious adherents primarily related to the ability to congratulate the holidays (such as congratulating Christmas) to followers of other religions. The questions asked are; In your opinion, is saying congratulations to the followers of other religions (eg 
congratulating Christmas) is permissible ?, the tendency of respondents to respond positively to this question is only $20 \%$, ie $5 \%$ say strongly agree and $15 \%$ agree. $80 \%$ of respondents refused the ability to congratulate the feast on followers of other religions, namely $50 \%$ said they did not agree and the other $30 \%$ stated strongly disagree.

\section{Tabel 3}

Do you think that wishes to celebrate the feast of other religions (eg saying good-bye) is it possible?

Answer Percent (\%)

Strongly Agree 5

Agree 15

Disagree 50

Strongly Disagree 30

Total of 100

The third question is oriented to measuring the tendency of the respondent's attitude towards active tolerance as indicated by the ability to congratulate holidays for followers of other religions. Based on the respondent's answers, the majority of respondents were still in an attitude that assumed that Islam forbade saying a happy holiday to followers of other religions.

The fourth question asks about the phenomenon of religious conversion as something normal. This question tracks the responses of respondents in responding to religious conversions with questions. Do you think conversion or conversion is common or prevalent? The general tendency of 


\section{Abdullah}

respondents to reject the phenomenon of religious conversion as normal or as much as $85 \%$, namely $45 \%$ said they did not agree and the other $40 \%$ stated strongly disagree. Respondents who gave a positive appreciation of the phenomenon of religious conversion were only $15 \%$ who agreed and none of the respondents stated strongly disagree.

\section{Tabel 4.}

\section{Do you think conversion or conversion is normal or common?}

Answer Percent (\%)

Strongly Agree 0

Agree 15

Disagree 45

Strongly Disagree 40

Total of 100

Reading from the tendency of respondents' answers shows that respondents tend to reject the phenomenon of religious conversion because religious conversion is something that is not normal. Based on the accumulation of respondents' answers it can be concluded that religious issues are exclusive, so religious conversion cannot be done easily.

The fifth question asks the most controversial aspect, which is about interfaith marriage. This theme on the abogard scale occupies the highest point in social distance between religious followers. This fifth question asks the respondent, How do you rate the practice of interfaith marriage chosen by 
some followers of religion? The tendency of respondents to give a positive appreciation of this problem is the lowest compared to the previous question about the paralysis of religious conversion. Only $10 \%$ of respondents gave a positive appreciation by expressing strongly agree (1\%) and agreeing $(9 \%)$. A total of $90 \%$ of respondents gave a negative appreciation, ie 53\% expressed disagreement and 37\% stated strongly disagree.

\section{Tabel 5.}

How do you rate the practice of interfaith marriage chosen by some followers of religion?

Answer Percent (\%)

Strongly Agree 1

Agree 9

Disagree 53

Strongly Disagree 37

Total of 100

Based on the respondent's answers showing the tendency of most respondents to reject the practice of interfaith marriage, only $10 \%$ of the respondents in the pluralism approach tended to be at the highest point, namely reaching agreement regarding the practice of interfaith marriage.

Looking at the tendency of respondents' answers to five questions in the Islamic sub-variables and the issue of religious pluralism, it appears that the general trend of respondents with regard to Islam and the issue of religious 
pluralism shows the rejection of most respondents on issues and practices promoted in religious pluralism. The only thing that respondents positively appreciate is about respecting the truth that exists in other religions. The other four questions tend to be responded negatively by most respondents with intervals between $70 \%-90 \%$. This shows that the response and attitude of respondents to Islam and the issue of religious pluralism are only at the level of tolerance. Controversial issues surrounding religious pluralism such as all religions as a way of salvation, congratulating other religious holidays, religious conversion, and the practice of interfaith marriage tend to be rejected by most respondents. To compare the respondents' answers to five questions related to Islam and the issue of religious pluralism can be seen in the following table:

\section{Tabel 6.}

Comparison of respondents' answers to five questions on Islamic sub-variables and the issue of religious pluralism.

\begin{tabular}{|c|l|r|r|r|r|}
\hline No & \multicolumn{1}{|c|}{ Questions } & $\begin{array}{c}\text { SS } \\
\mathbf{( \% )}\end{array}$ & S(\%) & $\begin{array}{r}\text { TS } \\
\mathbf{( \% )}\end{array}$ & $\begin{array}{r}\text { STS } \\
\mathbf{( \% )}\end{array}$ \\
\hline 1 & $\begin{array}{l}\text { Religion is the way of } \\
\text { salvation }\end{array}$ & 21 & 30 & 40 \\
\hline 2 & $\begin{array}{l}\text { Appreciation of truth in other } \\
\text { religions }\end{array}$ & 20 & 50 & 20 & 10 \\
\hline 3 & $\begin{array}{l}\text { Congratulate other religious } \\
\text { holidays }\end{array}$ & 5 & 15 & 50 & 30 \\
\hline
\end{tabular}




\begin{tabular}{|c|l|r|r|r|r|}
\hline 4 & $\begin{array}{l}\text { The phenomenon of religious } \\
\text { conversion }\end{array}$ & 0 & 15 & 45 & 40 \\
\hline 5 & Interfaith marriage practices & 1 & 9 & 53 & 37 \\
\hline
\end{tabular}

\section{B. Islam and Intellectual Discourse}

The second sub-variable of this study is Islam and intellectual discourse, in this sub-variable the respondents were asked their responses regarding matters relating to intellectual discourse in understanding Islam. There are four questions in this sub-variable, namely;

The first question that asked respondents about their use of philosophy in understanding religious doctrines was positively appreciated by most respondents. As many as $82 \%$ of respondents agreed to the use of philosophy in understanding religious doctrine, which consisted of $18 \%$ who strongly agreed and 64\% of other respondents agreed. Only 18\% of respondents refused or disapproved of the use of philosophy in understanding religious doctrines, namely $12 \%$ said they did not agree and the other $6 \%$ stated strongly disagree. This shows that the general tendency of respondents is quite appreciative of philosophy, especially when philosophy is used as an approach to understanding religious doctrine. For them, philosophy is not just a tool or a way of thinking that is sometimes assumed by some groups of Islamic organizations to be misguided and misleading knowledge but philosophy for them is a method of thinking that precisely makes religious understanding rational and leads 


\section{Abdullah}

to radical thoughts or thoughts that arrive the roots can touch on the substance of the problem.

\section{Tabel 7.}

What do you think, that philosophy can be used as an approach to understanding religious doctrines?

\begin{tabular}{|l|l|}
\hline \multicolumn{1}{|c|}{ Answer } & Persen $(\%)$ \\
\hline Strongly agree & 18 \\
\hline Agree & 64 \\
\hline Disagree & 12 \\
\hline $\begin{array}{l}\text { Strongly } \\
\text { Disagree }\end{array}$ & 6 \\
\hline Total & 100 \\
\hline
\end{tabular}

Based on the tendency of answers from respondents it can be concluded that respondents tend to be open to the use of rationality in understanding religious doctrines. The second question asks the respondent's attitude about the use of social and humanities approaches in interpreting the Koran. The purpose of this question is to find out the openness of the thoughts and views of the respondents related to the Qur'anic interpretation study, especially when faced with an orthodox view that forbids the use of scientific methods from the West in understanding the interpretation of the Koran. In this question compared to the previous question, respondents who gave a positive appreciation of the use of social sciences and humanities in the Qur'anic interpretation were lower than respondents who agreed to use a philosophical approach in understanding religious doctrine. 
In this question only $75 \%$ of respondents stated that the agreement consisting of $13 \%$ stated strongly agree and $62 \%$ agreed. As many as $25 \%$ of respondents gave a negative appreciation, which consisted of 15\% said they did not agree and the other $10 \%$ stated strongly disagree.

\section{Tabel 8.}

What do you think of the efforts of some Muslim intellectuals who use social sciences and humanities, such as hermeneutics in interpreting the Koran?.

\begin{tabular}{|l|l|}
\hline \multicolumn{1}{|c|}{ Answer } & Persen (\%) \\
\hline Strongly agree & 13 \\
\hline Agree & 62 \\
\hline Disagree & 15 \\
\hline $\begin{array}{l}\text { Strongly } \\
\text { Disagree }\end{array}$ & 10 \\
\hline Total & 100 \\
\hline
\end{tabular}

Based on the respondents' answers it was found that the general tendency of respondents to be open-minded in understanding the interpretation of the Koran, namely by agreeing to the use of modern sciences, especially social sciences and humanities (eg hermeneutics) in interpreting the Koran. This data shows that respondents are generally not rigid and closed minded and are open to the use of new methods in the study of Qur'anic interpretations. 
The third question asks how do you think of the efforts of non Muslims (orientalists) who study the Koran and hadith ?. The purpose of this question is to find out the openness of respondents to Islamic studies conducted by Orientalists / Islamologists who are not Muslim.

\section{Tabel 9.}

What do you think about non-Muslims (orientalists) who study the Qur'an and the Hadith?

\begin{tabular}{|l|l|}
\hline \multicolumn{1}{|c|}{ Answer } & Persen (\%) \\
\hline Strongly agree & 15 \\
\hline Agree & 45 \\
\hline Disagree & 30 \\
\hline Strongly Disagree & 10 \\
\hline Total & 100 \\
\hline
\end{tabular}

Based on the answers of respondents, there was a general tendency of respondents who were open to the efforts of Orientalists in conducting the study of the Koran and Hadith, even though the number of those who refused was not said to be small $(40 \%)$. Such views from some respondents need to be formulated so that they are more open-minded.

The fourth question as well as the final question in this sub variable is; Understanding and interpreting the Koran and Hadith is not enough just to rely on the meaning of 
harfiyah (textual), but by the process of adjustment (interpretation) with the present (contextual), your opinion? This question aims to find out the respondent's paradigm related to the Qur'anic interpretation between textual and contextual approaches.

\section{Tabel 10.}

Understanding and interpreting the Koran and Hadith is not enough just to rely on the meaning of harfiyah (textual), but by the process of adjustment (interpretation) with the present (contextual), your opinion?

\begin{tabular}{|l|c|}
\hline \multicolumn{1}{|c|}{ Answer } & Persen (\%) \\
\hline Strongly agree & 39 \\
\hline Agree & 48 \\
\hline Disagree & 9 \\
\hline Strongly Disagree & 4 \\
\hline Total & 100 \\
\hline
\end{tabular}

Looking at the tendency of respondents' answers to four questions in sub-Islamic variables and the issue of religious pluralism, it appears that the general tendency of respondents regarding Islam and intellectual discourse shows that the general tendency of respondents is people who have an open view of intellectual discourse and their use in understanding science Islam. The majority of respondents agreed with the use of a philosophical approach in understanding religious dogmas, the use of social and humanities approaches, and contextual interpretations in 


\section{Abdullab}

understanding the Koran and hadith with a percentage range between $75 \%$ and $87 \%$ of respondents. The lowest response from respondents was only on the third question that asked the respondents opinion about non-Muslims (orientalists) who studied the Koran, the approval level for this item was only $60 \%$. In general, there is a positive tendency of respondents to use intellectual discourse in Islam, at least it can be concluded that respondents are those who have intellectual and accommodating discourse tendencies towards the use of various scientific approaches (philosophy, social, humanities and contextual interpretations) in understanding Islamic scientific repertoire, especially those that are dogmatic as contained in the passages of the Qur'an and hadith.

Tabel 11.

Comparison of respondents' answers to five questions on Islamic sub-variables and issues of intellectual discourse

\begin{tabular}{|l|l|l|l|l|l|}
\hline No & \multicolumn{1}{|c|}{ Question } & $\begin{array}{c}\text { SS } \\
\mathbf{( \% )}\end{array}$ & $\begin{array}{c}\text { S } \\
\mathbf{( \% )}\end{array}$ & $\begin{array}{c}\text { TS } \\
\mathbf{( \% )}\end{array}$ & $\begin{array}{l}\text { STS } \\
\mathbf{( \% )}\end{array}$ \\
\hline 1 & $\begin{array}{l}\text { Use of a philosophical } \\
\text { approach }\end{array}$ & 18 & 64 & 12 & 6 \\
\hline 2 & $\begin{array}{l}\text { Use of social sciences and } \\
\text { humanities }\end{array}$ & 13 & 62 & 15 & 10 \\
\hline 3 & $\begin{array}{l}\text { Non-Muslims who study the } \\
\text { Koran }\end{array}$ & 15 & 45 & 30 & 10 \\
\hline
\end{tabular}




\begin{tabular}{|l|l|l|l|l|l|}
\hline 4 & Contextual interpretation & 39 & 48 & 9 & 4 \\
\hline
\end{tabular}

\section{Formalisme Islam (Hubungan Islam dan Negara)}

The third sub variable of this study is about the issue of Islamic formalism or the relationship between Islam and the State in the view of the respondents. There are four questionnaire questions in this sub-variable as a derivation of the concept of Islamic formalism in the life of the state. The four questions posed to respondents are;

Tabel 12.

What do you think about the discourse of enforcement (formalization)

\section{Islamic law in Indonesia?,}

\begin{tabular}{|l|c|}
\hline \multicolumn{1}{|c|}{ Answer } & Persen (\%) \\
\hline Strongly agree & 20 \\
\hline Agree & 60 \\
\hline Disagree & 15 \\
\hline Strongly Disagree & 5 \\
\hline Total & 100 \\
\hline
\end{tabular}

Based on respondents' answers, it was found that the general tendency of respondents was those who had a formalist paradigm in looking at the formalization of Islamic law in Indonesia. The reading factor and Islamic studies are the variables that influence the respondents' tendency, and the most influential is the effect of social media which often contains propaganda content formalizing Islamic law as an anti-thesis of the system 
The second question asks how do you assess the proliferation of local regulations (regional regulations) that are formulated by the regional government and the DPRD?

\section{Tabel 13.}

How do you evaluate the proliferation of local regulations (regional regulations) that are formulated by the regional government and DPRD?

\begin{tabular}{|l|c|}
\hline \multicolumn{1}{|c|}{ Answer } & Persen (\%) \\
\hline Strongly agree & 7 \\
\hline Agree & 61 \\
\hline Disagree & 29 \\
\hline Strongly Disagree & 3 \\
\hline Total & 100 \\
\hline
\end{tabular}

Based on the tendency of respondents' answers it can be seen that the approval of the implementation of the Shari'a regional regulation is still agreed upon by most respondents. The difference of $12 \%$ among respondents who agree with the discourse on the application of Islam in Indonesia and the application of Sharia regulations shows that $12 \%$ of respondents agree that the struggle to implement Islamic law emphasizes constitutional struggle in the national scale, not local scale.

The third question asks What is your view on the efforts of mass Islamic groups / organizations that seek to uphold Islamic Caliphate? As the two previous questions, the 
general tendency of respondents is to approve Islamic formalism on a global scale through the Khilafah Islamiyah system. This agreement showed that Islamic political formalism was affirmed by the majority of respondents. As many as $77 \%$ of respondents affirmed the efforts of mass Islamic groups / organizations that sought to uphold the Khilafah Islamiyah, which consisted of $15 \%$ who stated strongly in agreement and 62\% agreed. As such, only 23\% of respondents rejected the efforts of mass Islamic groups / organizations that sought to uphold the Khilafah Islamiyah, which consisted of $14 \%$ who disagreed and $9 \%$ of the other respondents stated strongly disagree.

\section{Tabel 14.}

How do you view the efforts of Islamic mass groups / organizations that seek to enforce the Islamic Caliphate?

\begin{tabular}{|l|l|}
\hline \multicolumn{1}{|c|}{ Answer } & Persen (\%) \\
\hline Strongly agree & 15 \\
\hline Agree & 62 \\
\hline Disagree & 14 \\
\hline Strongly Disagree & 9 \\
\hline Total & 100 \\
\hline
\end{tabular}

Reading the tendency of answers from respondents shows that there is a tendency towards great sympathy from respondents towards the struggle of Hizb ut-Tahrir, even though this organization has been banned by the government.

\section{Tabel 15.}


Do you agree with the statement? that Islam is a private matter and has nothing to do with politics and government.

\begin{tabular}{|l|l|}
\hline Answer & $\begin{array}{l}\text { Persen } \\
\mathbf{( \% )}\end{array}$ \\
\hline Strongly agree & 3 \\
\hline Agree & 9 \\
\hline Disagree & 60 \\
\hline $\begin{array}{l}\text { Strongly } \\
\text { Disagree }\end{array}$ & 28 \\
\hline Total & 100 \\
\hline
\end{tabular}

Based on the respondents' answers, it was shown that respondents viewed the perfection of Islam not only covering the private aspects, but the perfection of Islam because Islam is a religion that regulates in detail all aspects of human life, both in the private and public spheres. Respondents' answers are equivalent to their answers to previous questions about the formalization of Islam in the political life of the state.

Looking at the tendency of respondents' answers to four questions in sub-Islamic variables and the issue of religious pluralism, it appears that the general tendency of respondents with regard to Islamic formalism or Islamic and State relations shows a very formalist tendency to understand the relations or relations of Islam and the State. Full support was given by most of the respondents to efforts to formalize Islam in the form of the application of Shari'a regulations by the regional government, enforcement of Islamic law in the 
Indonesian state system, to support the struggles carried out by certain organizations in upholding the Khilafah Islamiyah system. This formalist paradigm is equivalent to the paradigm of the majority of respondents who hold that Islam is not a religion that merely regulates private matters, Islam is understood as a complete religion that regulates all aspects of human life systemically, including in the life of the government. This paradigm is the epistemic basis of the respondents in supporting all forms of Islamic formalism in the state system of life. More complete comparison of respondents' answers to four questions in the sub-variables of Islamic formalism (Islamic and State relations) can be seen in the following table:

Tabel 16.

Comparison of respondents' answers to five questions on sub-variables of Islamic Formalism (Islamic and State Relations)

\begin{tabular}{|l|l|l|l|l|l|}
\hline No & Question & $\begin{array}{l}\text { SS } \\
\mathbf{( \% )}\end{array}$ & $\begin{array}{l}\text { S } \\
\mathbf{( \% )}\end{array}$ & $\begin{array}{l}\text { TS } \\
\mathbf{( \% )}\end{array}$ & $\begin{array}{l}\text { STS } \\
\mathbf{( \% )}\end{array}$ \\
\hline 1 & $\begin{array}{l}\text { Discourse on the } \\
\text { enforcement of } \\
\text { Islamic law }\end{array}$ & 20 & 60 & 15 & 5 \\
\hline 2 & $\begin{array}{l}\text { Application of } \\
\text { Regional Regulation }\end{array}$ & 7 & 61 & 29 & 3 \\
\hline 3 & $\begin{array}{l}\text { The Battle of the } \\
\text { Khilafah Islmiyah }\end{array}$ & 15 & 62 & 14 & 9 \\
\hline
\end{tabular}




\begin{tabular}{|l|l|l|l|l|l|}
\hline 4 & $\begin{array}{l}\text { Islam is a private } \\
\text { religion }\end{array}$ & 3 & 9 & 60 & 28 \\
\hline
\end{tabular}

\section{Persepsi tentang Kekerasan Atas Nama Agama}

The fourth sub-variable of this study is the perception of violence in the name of religion. The first question of the sub-variable question of Religion must be disseminated to anyone even though by force, this question aims to determine the paradigmatic tendencies of the respondents regarding the spread of Islam to people outside of Islam.

Based on the respondent's answers, it shows the general tendency of respondents who reject propagandist propagation mainly through using coercion. The majority of respondents still hold that the spread of religion still has to respect the prevailing rules so that there are no horizontal problems or conflicts, other than that the spread of religion by coercion is contrary to the Koran. As many as $93 \%$ of respondents rejected the view that religion must be distributed to anyone even though by force. $38 \%$ of respondents stated strongly disagree and $55 \%$ of other respondents said they did not agree. A small number of respondents or as many as 7\% stated their affirmation towards the spread of religion to anyone even though by force. As many as $2 \%$ of respondents stated that they strongly agreed and as many as $5 \%$ of the other respondents agreed on this. 


\section{Tabel 17.}

Religion must be passed on to anyone even by means of coercion?,

\begin{tabular}{|l|l|}
\hline Answer & $\begin{array}{l}\text { Persen } \\
\mathbf{( \% )}\end{array}$ \\
\hline Strongly agree & 2 \\
\hline Agree & 5 \\
\hline Disagree & 55 \\
\hline $\begin{array}{l}\text { Strongly } \\
\text { Disagree }\end{array}$ & 38 \\
\hline Total & 100 \\
\hline
\end{tabular}

Based on the respondent's answers, the paradigm of da'wah respondents who were quite moderate showed that religion (Islam) should not be disseminated by force.

As the previous question, the agreement of the respondents about the use of methods of violence in the enforcement of the amar ma ruf nahy munkar was only agreed by $7 \%$ of respondents with the same details, namely $2 \%$ of respondents stated strongly agree and $5 \%$ of other respondents agreed. Most respondents or 93\% refused the methods of violence in the enforcement of amar ma'ruf nahy munkar. The number of respondents who rejected this was the same as the rejection of the spread of religion by force. As many as $40 \%$ of respondents stated strongly disagree and the other $53 \%$ said they did not agree to the behavior of violence in the enforcement of amar ma; rah nahy munkar. 
Tabel 18.

What do you think about the attitude of a group of Muslims who are busy with rape?

\begin{tabular}{|l|l|}
\hline Answer & $\begin{array}{l}\text { Persen } \\
\mathbf{( \% )}\end{array}$ \\
\hline Strongly agree & 2 \\
\hline Agree & 5 \\
\hline Disagree & 53 \\
\hline Strongly Disagree & 40 \\
\hline Total & 100 \\
\hline
\end{tabular}

Based on the respondents' answers, it was found that the general tendency to reject the forms of violence carried out in the name of enforcement of amar ma'ruf nahy munkar. This shows the tendency of most respondents who are very moderate and do not like the use of methods of violence. On the contrary, $7 \%$ of respondents are consistent with their attitudes which agree and even strongly agree with the methods of violence pursued. This needs to be considered that the great potential of radicalism among respondents is $7 \%$.

\section{Tabel 19.}

What do you think of the method of jihad carried out by a certain group of religions with a mode of violence, for example by bombing?

\begin{tabular}{|l|l|}
\hline Answer & Persen (\%) \\
\hline Strongly agree & 0 \\
\hline Agree & 0 \\
\hline
\end{tabular}




\begin{tabular}{|l|l|}
\hline Disagree & 31 \\
\hline $\begin{array}{l}\text { Strongly } \\
\text { Disagree }\end{array}$ & 69 \\
\hline Total & 100 \\
\hline
\end{tabular}

Based on the answers given by respondents, it can be concluded that none of the respondents had the potential to become terrorists, because none of them agreed to acts of violence under the pretext of jihad as practiced by terrorist groups. $100 \%$ of respondents opposed all forms of terrorist acts showing the respondent's moderation in understanding jihad and the mode of violence.

Judging from the tendency of respondents' answers to the three questions in the perception sub-variable on acts of violence in the name of religion, respondents generally reject all forms of violence in the name of religion both in terms of the spread of religion, enforcement of religious law to the mode of violence in the jihad. Moderate attitudes were shown by respondents through rejection of the three items of violence in the name of the religion. But the interesting data is that there are $7 \%$ of respondents who tend to be radical because they approve acts of violence in the spread of religion and enforcement of amar ma'ruf nahymunkar. The potential of radicalism shown by $7 \%$ of respondents does not lead to the potential of terrorism, because they also reject the mode of violence which is carried out as a method of jihad as practiced by terrorist groups. . More complete about the comparison of respondents' answers to the three questions on 
the sub variable of the action of violence in the name of religion, can be seen in the following table:

\section{Tabel 20.}

Comparison of respondents' answers to five questions on the perception sub-variables about acts of violence in the name of religion

\begin{tabular}{|l|l|l|l|l|l|}
\hline No & \multicolumn{1}{|c|}{ Question } & $\begin{array}{c}\text { SS } \\
\mathbf{( \% )}\end{array}$ & $\begin{array}{c}\text { S } \\
\mathbf{( \% )}\end{array}$ & $\begin{array}{c}\text { TS } \\
\mathbf{( \% )}\end{array}$ & $\begin{array}{l}\text { STS } \\
\mathbf{( \% )}\end{array}$ \\
\hline 1 & Spread of religion by force & 2 & 5 & 55 & 38 \\
\hline 2 & $\begin{array}{l}\text { Enforcement of illiterate nahy } \\
\text { munkar with violence }\end{array}$ & 2 & 5 & 53 & 40 \\
\hline 3 & $\begin{array}{l}\text { Method of jihad with a violent } \\
\text { mode }\end{array}$ & 0 & 0 & 31 & 69 \\
\hline
\end{tabular}

\section{E. Variabel Comparison Analysis among variables}

Based on the data analyzed from the overall answers of respondents in 20 questions from 4 sub-variables this study shows that in the two sub-answers variable respondents showed a positive tendency, that is in Islamic sub-variables and intellectual discourse and sub perception variables about acts of violence in the name of religion. In these two subvariables, the moderate understanding and religious attitudes of the respondents were shown by an appreciative attitude towards the use of intellectual discourse in Islamic studies, such as philosophy, social sciences and humanities, and contextual approaches to understanding the Koran and 
hadith. In the perception sub-variable about acts of violence in the name of religion, moderate tendency is very evident from the answers of most respondents to the phenomenon of acts of violence in the name of religion. The total answers in this sub-variable indicate a moderate attitude of respondents who reject all forms of coercion and violence in fighting for religion. Among all the sub-variables in this study, the subvariables of perceptions of acts of violence in the name of religion most indicated the morality of almost all respondents.

In the other two sub-variables, the total answers given by respondents showed the religious understanding of respondents who seemed to be exclusive, namely in the subvariables of Islam and around the issue of religious pluralism and sub-variables of Islamic formalism (Islamic and State relations). In the Islamic sub-variables and around the issue of pluralism, the tendency of most respondents to reject the themes promoted by religious pluralism, namely; the concept of the safety of all religions, congratulating the holiday, the phenomenon of religious conversion, and the practice of interfaith marriage, but showing a positive trend when asked about respect for the truths held by other religions. Rejection of the issue of religious pluralism can be understood because of theological factors that tend to be exclusive from some respondents. The conclusion of the total respondents' answers to this variable is the religious understanding and attitude of the respondents in general is exclusive with regard to the issue of pluralism, but still within the frame of Islam that is tolerant in aspects of respect for diversity. 
Islamic formalism sub-variables (relations between Islam and the State) show the tendency of respondents who have formalist paradigms. Among all the variables asked in this study, it is this variable that best shows the exclusive religious understanding of the respondents. Most of the respondents were supporters of Islamic formalism in the life of the state starting from the application of Shari'a regional regulations, enforcement of Islamic law in the context of the Indonesian State, to the sympathy and support of most respondents in the struggle to uphold the Khilafah Islamiyah system.

In general, all respondents' answers to all the questions and sub-variables of the study showed that the respondent's religious beliefs and attitudes were basically still in the "Middle-Right" category. The meaning and understanding of the respondent's religious attitudes actually shows moderate and accommodating views and attitudes, for example in intellectual discourse and opposition to violence in the name of religion. However, the "Middle" position in attributing respondents' religious tendencies and attitudes tends to lead to the "Right" paradigm, especially when it comes in contact with the issue of pluralism and the formalization of Islam in state life.

\section{Conclusion}

From a number of views of respondents in this study can be concluded several conclusions, among others. 
First, on sub-variables concerning Islam and intellectual discourse and perceptions of acts of violence in the name of religion. They are responded to moderately and positively

Second, in the other two sub-variables, respondents' answers indicated that religious beliefs tended to be exclusive, namely in Islamic sub-variables and around the issue of religious pluralism and sub-variables of Islamic formalism (Islamic and State relations). In the Islamic sub-variables surrounding the issue of pluralism shows the tendency of most respondents to reject the themes promoted by religious pluralism, namely; the concept of the safety of all religions, congratulating the holidays, the phenomenon of religious conversion, and the practice of interfaith marriage, but showing a positive trend.

Third, the third and fourth sub-variables showed that the religious attitude and understanding of students from Bima district in Alauddin UIN were open and moderate and responded positively to the attitude of violence against other religions or schools, then were inclusive in matters of religious pluralism. Then on the issue of the formalism of establishing an Islamic state they considered disagreeing because the Indonesian state based on Pancasila was an interpretation of the Qur'an and hadith. Likewise, on the issue of congratulating a holiday for those who consider it normal or just what is important depends on the intention whether theologically or sociologically. 


\section{REFERENCES}

Arkunto, Suharsini. Prosedur Penelitian: Studi Pendekatan

Praktek. Jakarta: Rineka Cipta. 2010.

Badan Litbang dan Diklat Kementerian Agama RI. Survey

Tingkat Kesalehan Masyarakat Muslim Indonesia. Jakarta:

Badan Litbang dan Diklat Departemen Agama. 2007.

Bidang Kehidupan Keagamaan Balai Litbang Agama

Makassar. Paham dan Sikeap Keagamaan Mahasiswa Muslim

di Kawasan Timur Indonesia. Makassar: Laporan Penelitain, 2010.

Bungin, Burhan. Metodologi Penelitian Kuantitatif: Komunikasi, Ekonomi, dan Kebijakan Publik, serta Ilmu-ilmu Sosial Lainnya. Jakarta: Kencana. 2010.

Habibullah, Ahmad. Religuisitas dan Psikologi Agama, (Yogyakarta: Pustaka Adiyatma, 2007.

Haddad, Saleh. Islam Warna-warni, Solo: Pustaka Fikr. 2002.

Jaiz, Hartono Ahmad Ada Pemurtadan di IAIN, (Jakarta:

Pustaka al-Kautsar, 2005).

Jamaluddin, Ancok dkk. Psikologi Islam: Solusi atas Problemproblem Psikologi. Yogyakarta: Pustaka Pelajar. 1994.

Khuzman, Charles. Wacana Islam Liberal: Pemikiran Islam

Kontemporer tentang Isu-isu Global. Jakarta: Paramadina. 2001.

Moleong, Lexy. Metodologi Penelitian Kuantitatif. Bandung: Remaja Rosdakarya. 2007.

Nazir, Mohammad. Metode Penelitian. Jakarta: Ghalia Indonesia. 2005. 
Sugiyono. Metode Penelitian Kuantitatif, Kualitatif, dan R\&DD. Bandung: Alfabeta. 2011.

Zada, Hamzah Islam Radikal: Pergulatan Ormas-ormas Islam Garis Keras di Indonesia, Jakarta: Teraju. 2002.

Chambert Loit Henri dan Siti Maryam R. Salahuddin, BO' Sangaji kai Catatan Kerajaan Bima,Jakarta ; Yayasan Obor Indonesia, 1999.

Chambert Loir Henri, Kerajaan Bima dalam Sastra dan Sejarah, Jakarta; Kepustakaan Populer Gramedia, 2004.

Depdikbud, Sejarah Pendidikan Nusa Tenggara Barat, Jakarta: Depdikbud, 1984.

HM Zaenuddin, Asal Usul Kota-Kota di Indonesia Tempo doeloe,Jakarta ; Zaytuna Ufuk Adabi, 2013.

Hamka, Pribadi, Cet. XI, Jakarta: Bulan Bintang, 1982.

H.A.Rahim Junaidin, Skripsi Kesultanan Bima (Suatu Tinjauan Ketatanegaraan Islam),Fakultas Adab IAIN Alauddin Ujung Pandang, Tahun 1992 Hasbullah,

Hadi Sutrisno, Metodologi Research,Yogyakarta: Yasbit Fak. Psikologi UGM, 1976.

Ismail M. Hilir dan Alam Malingi, Profil Raja dan Sultan Bima,Bima; Dinas Budaya dan Pariwisata, 2010.

Peranan Kesultanan Bima dalam Perjalanan Sejarah Nusantara,Mataram; Lengge, 2004.

Mahfud Yahya, Pekembanagan Yayasan Islam Bima, Bima:

Kantor Yayasan Islam Kabupaten Bima, 1971.

Quraisy, Abdullah Masser. Riwayat Hidup Sultan Mubammad Salabuddin, Ketikan Bima: 1980. 
Abdullah

Rachman M. Fachrir, Kontroversi Sejarah Kehadiran Islam di Bima, Jurnal Studi Islam dan Masyarakat Vol IX Edisi 15 No 1 Januari-Juni 2005 (Mataram: Ulumuna, 2005) 